Biogeosciences Discuss., 5, 2401-2423, 2008

www.biogeosciences-discuss.net/5/2401/2008/

(C) Author(s) 2008. This work is distributed under

Mass extinctions past and present

S. A. Wooldridge

\title{
Mass extinctions past and present: a unifying hypothesis
}

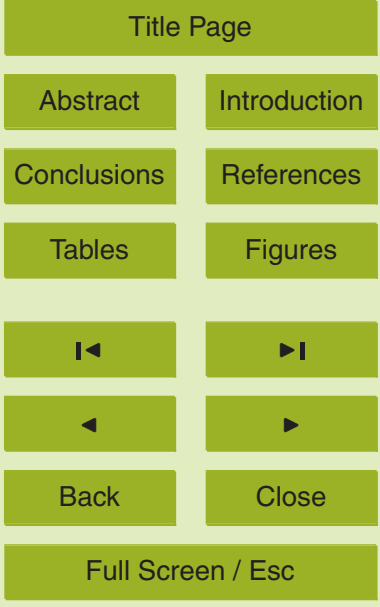

Printer-friendly Version

Interactive Discussion 


\section{Abstract}

Enzymes are often referred to as the "agents of life" - a very apt term, since essentially all life processes are controlled by them. Typically, these enzymes only function across a narrow band of environmental conditions, particularly temperature and $\mathrm{pH}$. Ambi5 ent conditions that challenge these operating conspecifics trigger enzyme dysfunction. Here, it is proposed that the $\mathrm{pH}$-dependent inactivation of a single enzyme, urease, provides a unifying kill-mechanism for at least four of the "big five" mass extinctions of the past $\mathbf{5 6 0}$ million years. The triggering of this kill-mechanism is suggested to be sensitive to both gradualistic and catastrophic environmental disturbances that cause the operating $\mathrm{pH}$ of urease-dependent organisms to cross enzymatic "dead zones", one of which is suggested to exist at $\sim \mathrm{pH} 7.9$. For a wide range of oceanic and terrestrial ecosystems, this $\mathrm{pH}$ threshold coincides with an atmospheric $\mathrm{CO}_{2}$ partial pressure $\left(p \mathrm{CO}_{2}\right)$ of $\sim 560 \mathrm{ppmv}$ - a level that at current $\mathrm{CO}_{2}$ emission trajectories may be exceeded as early as 2050 . The urease hypothesis thus predicts an impending Anthropocene extinction event of equivalence to the "big five" unless future atmospheric $p \mathrm{CO}_{2}$ levels can be stabilised well below 560 ppmv. Immediate scientific discussion and testing is required to confirm the validity of the urease hypothesis.

\section{Introduction}

Origination and extinction of species have occurred throughout the history of life, with the continual increase of diversity indicating the predominance of origination (Raup and Sepkoski, 1982). The only major reversals to this trend have occurred during mass extinctions. Mass extinctions are defined as the extinction of a significant proportion of the Earth's biota over a geographically widespread area in a geological insignificant period of time, often one that appears instantaneous when viewed at the level provided by the geological record. Known ominously as the "big five", most authors accept the occurrence of five such mass extinction events during the past 560 million years: the late-
BGD

$5,2401-2423,2008$

Mass extinctions past and present

S. A. Wooldridge

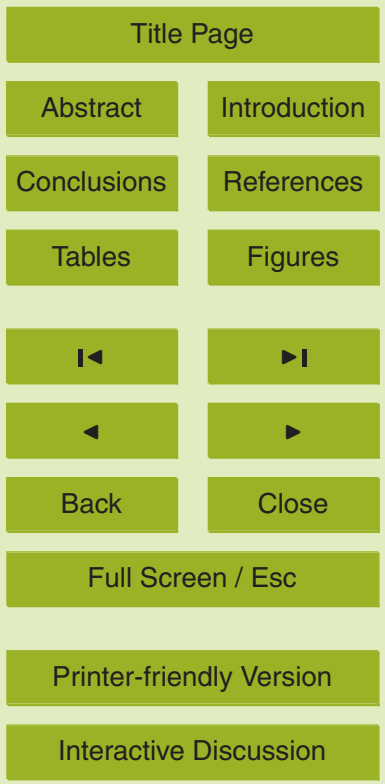

Interactive Discussion 
Ordovician ( 440 Ma), late-Devonian ( 370-350 Ma), end-Permian ( 250 Ma), endTriassic ( 220-200 Ma) and end-Cretaceous ( 65 Ma) events (Raup and Sepkoski, 1982; McGhee et al., 2004; Rohde and Muller, 2005). The marine extinction intensity across the Phanerozoic (Fig. 1a) highlights the infrequent but significant impact of 5 these events within the marine realm.

Research into the cause of mass extinction events was tremendously invigorated by the seminal work of Louis Alverez and colleagues, who proposed that a bolide impact was ultimately responsible for the end-Cretaceous extinction event (Alverez et al., 1980). Alternative catastrophic scenarios events have been proposed, including major 10 volcanism, and the rapid release of seafloor methane hydrates. More gradualistic processes that induce global climate change (warming or cooling), fluctuating sea levels, or oceanic anoxia have also been implicated. Geochemical and paleontology evidence suggest that no single triggering mechanism successfully explains the onset of all of the "big five" mass extinction events (Elewa, 2008). However, it is important to draw a clear distinction between kill and trigger mechanisms. A kill mechanism is the physiologically disruptive process that causes death, whereas a trigger mechanism is the critical disturbance that brings one or more kill mechanisms into play. Importantly, each kill mechanism predicts a physiology-dependent pattern of extinction and survival, thereby providing a test for geophysical hypotheses. The development of "testable" mechanistic explanations for mass extinctions events thus requires that trigger mechanisms inferred from geological data are integrated with kill mechanisms that are buttressed by paleophysiological support. What's more, a credible kill mechanism should: (i) explain all of the losses, not just focus on a few iconic groups (such as dinosaurs); (ii) explain why particular groups of organisms died out and why others survived - both on land as well as in the ocean; and (iii) be based on events or processes that can be demonstrated to happen, not just inferred from the extinction.

Here, an evidential based approach is used to propose that the $\mathrm{pH}$-dependent inactivation of a single specific enzyme, urease, satisfies all of the requirements necessary to be considered a potent kill mechanism for the late-Devonian, end-Permian, end-

BGD

$5,2401-2423,2008$

Mass extinctions past and present

S. A. Wooldridge

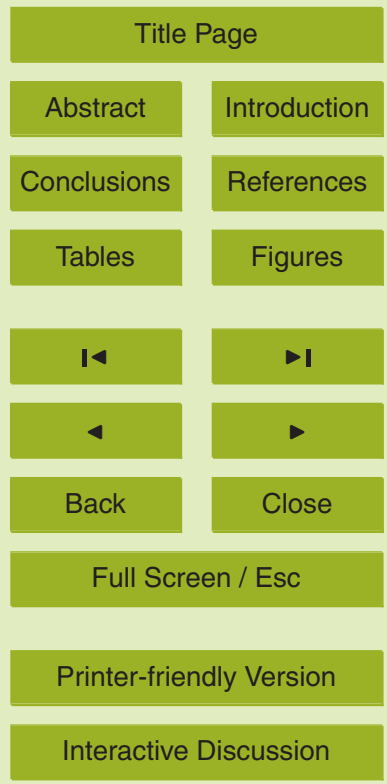

Interactive Discussion 
Triassic and end-Cretaceous events. The accuracy with which this new understanding allows these extinction events to be unified provides a strong rationale from which to warn of an impending Anthropocene extinction event unless future atmospheric $p \mathrm{CO}_{2}$ levels can be stabilised below 560 ppmv.

\section{BGD}

$5,2401-2423,2008$

Mass extinctions past and present

S. A. Wooldridge

Urease (EC 3.5.1.5, urea amidohydrolase) is a nickel-dependent metalloenzyme that catalyses the near instantaneous hydrolysis of urea $\left(\mathrm{NH}_{2} \mathrm{CONH} \mathrm{H}_{2}\right)$ to form ammonia $\left(\mathrm{NH}_{3}\right)$ and carbon dioxide $\left(\mathrm{CO}_{2}\right)$. The half-time of the uncatalyzed decomposition of urea is $~ 3.6$ years, which confirms urease as the most proficient enzyme identified 10 to date (Estiu and Merz, 2004). Numerous organisms synthesize urease, including terrestrial plants, marine algae, bacteria, fungi and invertebrates (including marine crustaceans). This wide biological distribution does not however include vertebrates (Urich, 1994) - though bacteria found within the digestive tract of vertebrates is known to synthesize urease e.g. the human pathogen Helicobacter pylori (Ha et al., 2001). 15 Molecular analysis demonstrates that urease protein sequences are highly conserved across eukaryotic and prokaryotic kingdoms; with all known ureases being structurally similar, including superimposable active sites that employ the same catalytic mechanism (Krajewska and Ciurli, 2005; Witte et al., 2005).

A key function of urease is to allow an organism to access external or internally 20 generated urea as a nitrogen source for cellular growth. Significant amounts of plant nitrogen flow through recycled urea (Sirko and Brodzik, 2000; Cantón et al., 2005). In this case, recycled urea derives from the catabolism of the amino acid, arginine, and possibly from the degradation of purines and ureides (Sirko and Brodzik, 2000). In addition to these pathways, organisms that possess the ornithine-urea cycle are also able

to recover urea from the routine catabolism of ingested and/or cellular protein (amino acid) sources. The role of urease in increasing the availability of nitrogen for cellular growth is particularly important during the early stages of an organism's development.

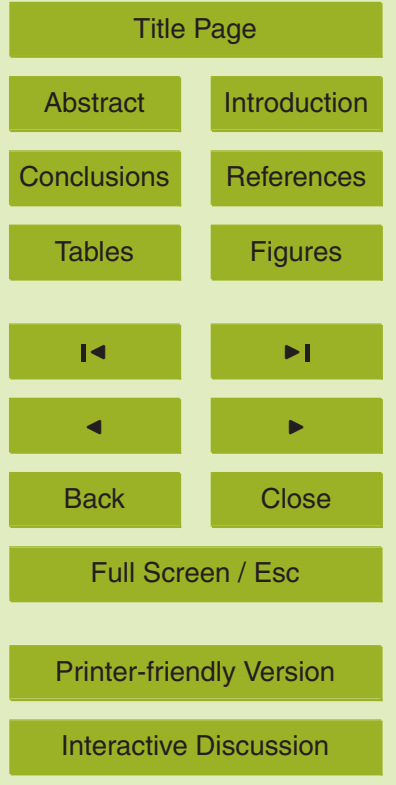

Interactive Discussion 
For example, a seed-specific urease converts the products arising from the breakdown of storage proteins into nitrogen sources that support the growth of both angiosperm and gymnosperm seedlings (Jones and Boulter, 1968; Zonia et al., 1995; Todd et al., 2001). Similarly, urease activity found within the eggs of marine invertebrates (e.g. sea 5 urchins: Brookbank and Whiteley, 1954) functions to mobilise nitrogen from storage compounds during the pre-feeding stages of embryo development.

A second important function of urease is in facilitating the biomineralisation of calcium carbonate $\left(\mathrm{CaCO}_{3}\right)$ by invertebrates (Campbell and Speeg, 1969; Crossland and Barnes, 1974). Indeed, urease inhibition has been shown to disrupt mineralisation in 10 land snails (Abolinš-Krogis, 1986) and gastropod molluscs (Pedrozo et al., 1997). A recent biomineralisation model (Wooldridge, submitted ${ }^{1}$ ) supports the involvement of urease in the initiation of nascent $\mathrm{CaCO}_{3}$ nanograins that underpin the initial stages of the biomineralisation process within invertebrates (Dauphin et al., 2007). The model builds upon the theoretical understanding that $\mathrm{NH}_{3}$ produced by urease-mediated hy15 drolysis of urea can neutralize the protons formed during calcification - thereby promoting the alkaline conditions required for spontaneous $\mathrm{CaCO}_{3}$ deposition (Campbell and Speeg, 1969; Crossland and Barnes, 1974). $\mathrm{CO}_{2}$ evolved from the reaction may also be sequestered by the calcification process (Crossland and Barnes, 1974). Increased ammonium ion $\left(\mathrm{NH}_{4}^{+}\right)$production in the hen oviduct during egg-laying (Campbell and Speeg, 1969) suggests that similar mechanisms have evolved to enable biological $\mathrm{CaCO}_{3}$ deposition in higher vertebrates.

Despite the efficiency and physiological importance of the urease enzyme, a key aspect to be highlighted here is its vulnerability to disruption due to a strong $\mathrm{pH}$ dependent activation - leading to apparent "dead zones" between multiple pH optima.

25 The active site cavity of urease features several ionisable amino acid residues that are conserved across all known ureases (Krajewska and Ciurli, 2005). Accordingly,

\footnotetext{
${ }^{1}$ Wooldridge, S. A.: A dual-enzyme biomineralisation model for interpreting the information stored within coral skeletons: I. Key processes and supporting evidence, submitted to Geochim. Cosmochim. Acta., 2008.
}

BGD

$5,2401-2423,2008$

Mass extinctions past and present

S. A. Wooldridge

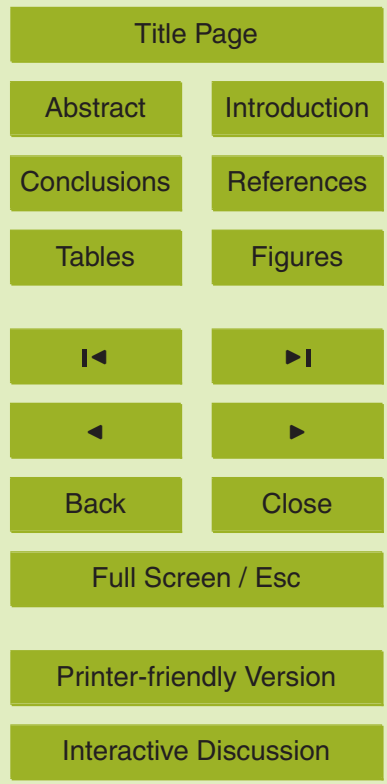

Interactive Discussion 
these groups along with the Ni-bound molecules are considered to be responsible for the observed $\mathrm{pH}$ profiles of urease kinetic parameters. Most frequently, biomodal $\mathrm{pH}$ profiles have been attributed to two macroscopic $\mathrm{pK}_{a}$ values, one being more acidic the other more basic. For example, two pH optimum (7.6 and 8.2), have been identi5 fied in the urease activity profile of the scleractinian coral Acropora acuminata (Barnes and Crossland, 1976) (Fig. 2). The visual interpretation of this result in terms of two overlapping bell-shaped curves is possibly overly simplistic, but serves to illustrate the potential for "dead zones" (e.g. pH 7.9) in the activation state of urease. Additional activity optima at lower $\mathrm{pH}$ values (Krajewska and Ciurli, 2005) suggest the existence of more than two ionisable groups of differing $\mathrm{pK}_{a}$ 's.

The relevance of the inactivation of urease activity at $\mathrm{pH} \sim 7.9$ to the mass extinction events at the late-Devonian, end-Permian, end-Triassic and end-Cretaceous becomes evident upon comparison of the marine extinction intensity and seawater $\mathrm{pH}$ estimates over the last 550 million years (Fig. 1b) - with transgression of the enzymatic 15 "dead zone" (from either above or below) coinciding with the initiation of these extinction events. In spite of the acknowledged uncertainty associated with these seawater $\mathrm{pH}$ estimates (Caldeira, 2007), the precision of the predictions supports the emerging geochemistry and paleontology evidence showing that the end-Triassic was marked by multiple extinctions at the Norian/Rhaetian ( 220 Ma) and Rhaetian/Hettangian 20 ( 201 Ma) stage boundaries (Ward et al., 2004).

It is well established that atmospheric $p \mathrm{CO}_{2}$ is a dominant driver of seawater $\mathrm{pH}$, with increased $p \mathrm{CO}_{2}$ causing a concomitant decrease in seawater $\mathrm{pH}$ (Caldeira and Berner, 1999). For the modern ocean-atmosphere system, a seawater $\mathrm{pH} \sim 7.9$ in the upper ocean is predicted to occur at $p \mathrm{CO}_{2}$ levels $\sim 560$ ppmv (Caldeira and Berner, 25 1999). Geochemical models (François et al., 2005) predict that this atmospheric $p \mathrm{CO}_{2}-$ seawater $\mathrm{pH}$ equivalence may have been broadly consistent since at least the lateDevonian extinction event (Fig. 1c). First order inference therefore suggests that the initiation of the enzymatic "dead zone" of urease $(\mathrm{pH} \sim 7.9)$ arises whenever a specific triggering condition - be it a catastrophic (e.g. volcanism) or gradualistic (e.g. silicate

\section{BGD}

$5,2401-2423,2008$

Mass extinctions past and present

S. A. Wooldridge

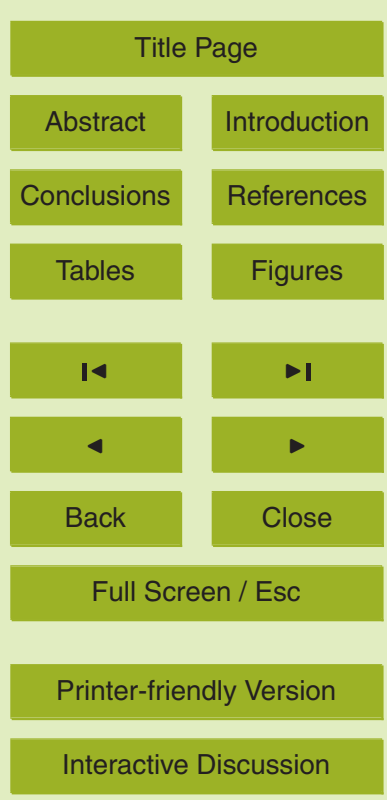


rock weathering) process - causes atmospheric $p \mathrm{CO}_{2}$ levels to cross $\sim 560 \mathrm{ppmv}$ (from either above or below). Marine organisms are clearly at most risk from the occurrence of this damaging sequence. However, many organisms maintain ambient bodily fluids of similar chemical composition to seawater, which also renders them susceptible to

5 altered acid-base status unless they possess the physiological capacity to buffer these bodily fluids against altered $p \mathrm{CO}_{2}$ levels (Knoll et al., 2007). Organisms that rely on a favourable tissue-to-environment gradient for $\mathrm{CO}_{2}$ excretion (e.g. due to limited elaboration of organs for circulation and gas exchange) are therefore potentially at high risk. Specific life history stages are also envisaged as being more vulnerable, such 10 as the embryonic stage of external seeds and eggs - since their porous protective layers permit equilibration with the prevailing external $p \mathrm{CO}_{2}$ condition. Furthermore, poikilothermic (cold-blooded) animals are known to exhibit an additional relationship between temperature and extracellular $\mathrm{pH}$, such that the $\mathrm{pH}$ of bodily fluids declines with increases in temperature at a rate $\sim 0.015$ unit $/{ }^{\circ} \mathrm{C}$ (Reeves, 1977).

15 The multiple $\mathrm{pH}$ optima of urease provide a viable explanation for why invertebrates were capable of precipitating carbonate skeletons beneath past atmospheres (e.g. during the mid-Mesozoic) that contained considerably higher $\mathrm{CO}_{2}$ concentrations than today (see, Fig. 1c). It is interesting to speculate that the Late Ordovician mass extinction may also be related to the transgression of another urease "dead zone" at a lower $\mathrm{pH}$ ( 7.3-7.4). Indeed, there is a suggestion that the early part of the sequence of extinction events across the late-Devonian extinction may have arisen at this lower $\mathrm{pH}$. Refinement of these suggestions awaits an improved characterisation of the activity profile of urease at lower $\mathrm{pH}$, in addition to more accurate estimates for Paleozoic $p \mathrm{CO}_{2}$, seawater $\mathrm{pH}$, and temperature.

\section{Testable physiological evidence}

Modern-day experimental results strongly support the existence of a physiological "dead zone" at $\mathrm{pH} \sim 7.9\left(\mathrm{COO}_{2} \sim 560 \mathrm{ppmv}\right)$ within organisms that synthesize urease.

\section{BGD}

$5,2401-2423,2008$

Mass extinctions past and present

S. A. Wooldridge

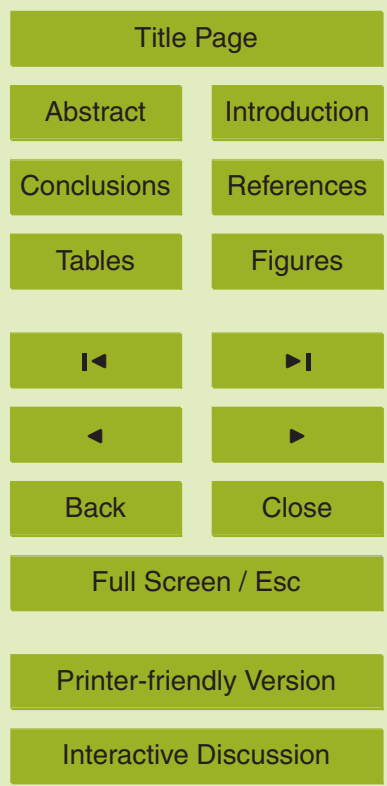


For example: (i) the 6-month survival rates of juvenile gastropods and echinoderms were significantly reduced when the experimental $p \mathrm{CO}_{2}$ seawater condition is set to 560 ppmv (pH 7.9) (Shirayama and Thorton, 2005). Even within the surviving populations, both the shell weight (calcification) and body mass (somatic tissue growth) were 5 significantly reduced in comparison to individuals grown at normal $p \mathrm{CO}_{2}$ levels; (ii) the calcifying strain of the coccolithophore Emiliania huxleyi displays a significant depression in growth rate ( $<10 \%$ of maximum) across the $\mathrm{pH}$ range from 8.1 to 7.6 (Johnston, 1996); (iii) mussels and oysters display a clear disconnect in growth performance at $\mathrm{pH}$ $\sim 7.9$, in addition to the more general decline in calcification rates arising from a re10 duction in carbonate ion $\left(\mathrm{CO}_{3}^{2-}\right)$ concentration (Gazeau et al., 2007); (iv) even whilst aragonite saturation levels remain superatsurated, net negative coral calcification (= dissolution) is initiated at $p \mathrm{CO}_{2} \sim 560 \mathrm{ppmv}$ within tropical reef corals (Yates and Halley, 2006); ( $v$ ) the aragonite sclerites embedded within the polyps of the soft coral Cladiella sp. undergo net dissolution at a seawater pH between 7.9-7.8 (Tentori and Allemand, 15 2006); (vi) measured urease activity and growth performance in the marine algae Ulva lactuca displays a clear disconnect at pH 7.9 (Bekheet et al., 1984); (vii) following an initial enhancement in biomass, nitrogen-limitation progressively suppresses the positive response of terrestrial plants to elevated $p \mathrm{CO}_{2}$ (560 ppmv) (Reich et al., 2006). This well known "progressive nitrogen limitation" effect (Finzi et al., 2006) causes overall plant nitrogen concentrations to drop by almost double what would be expected if a given amount of nitrogen were simply diluted by the addition biomass (Makino and Mae, 1999) - a result that is consistent with an expected impact of urease inhibition.

\section{Marine paleophysiological evidence}

In terms of the "big five" mass extinctions, the marine fossil record provides strong paleophysiological evidence for the proposed urease-inhibition kill mechanism.

\section{BGD}

$5,2401-2423,2008$

Mass extinctions past and present

S. A. Wooldridge

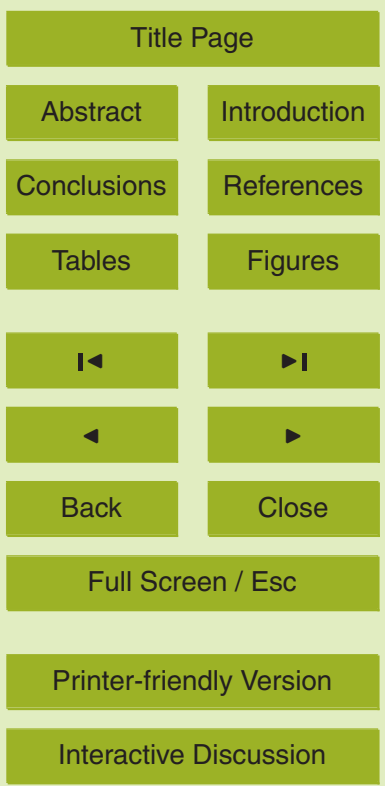




\subsection{Sensitive taxa}

Underpinning each of the mass extinctions events is a carbonate production crisis within the ocean realm - with organisms that deposit calcareous $\left(\mathrm{CaCO}_{3}\right)$ shells or skeletons being disproportionate targets for decimation or extinction (Wood, 1999).

5 Many authors have endeavoured to associate this carbonate production crisis with ocean chemistry, but have been frustrated by the limited relationship between extinction risk and skeletal mineralogy. For example, Kiessling et al. (2007) demonstrate that although calcareous benthic organisms displayed preferential extinction across the Triassic-Jurassic boundary, there is little evidence that those organisms which deposited the less stable high-Mg-calcite or aragonitic polymorph of $\mathrm{CaCO}_{3}$ were at greater risk than those which deposited the more stable low-Mg calcite. However, the importance of urease to the early stages of $\mathrm{CaCO}_{3}$ biomineralisation has been suggested to be independent of the final skeletal mineralogy (Wooldridge, submitted ${ }^{2}$ ) supporting the universal relevance of a $\mathrm{pH}$-dependent inhibition of urease for calcare-

ous organisms. Subtle species-specific differences in the timing of inhibition may arise due to different levels of physiological buffering in the fluids from which the skeleton is precipitated - an interpretation supported by the stepped, somewhat gradual demise of calcareous planktic species across the end-Cretaceous extinction boundary (Keller, 2001).

\subsection{Tolerant "Disaster" taxa}

Coeval with the demise of calcareous biota is the high survival rates and regional blooms of marine groups in which urease is not utilised for biomineralisation. These include: (i) silica-secreting organisms, such as the radiolarians and silicisponges at

\footnotetext{
${ }^{2}$ Wooldridge, S. A.: A dual-enzyme biomineralisation model for interpreting the information stored within coral skeletons: I. Key processes and supporting evidence, submitted to Geochim. Cosmochim. Acta., 2008.
}

BGD

$5,2401-2423,2008$

Mass extinctions past and present

S. A. Wooldridge

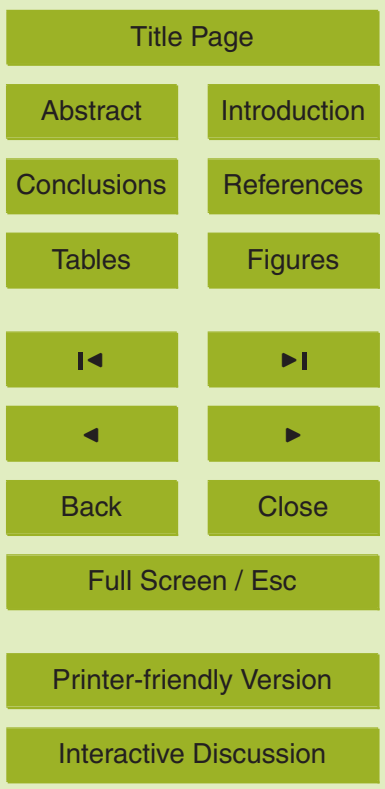

Interactive Discussion 
the end-Devonian, and the diatoms and radiolarians at the end-Cretaceous (reviewed by Racki, 1999); (ii) organisms that utilise cellulose-derived exterior coverings, such as foraminifera with agglutinated tests at the end-Permian (Knoll et al., 2007), and organicwalled phytoplankton at the end-Triassic and end-Cretaceous (van de Schootbrugge et 5 al., 2007). Similarly, marine organisms that were not reliant on any form of biomineralisation exhibited much higher survival rates. For example, Knoll et al. 2007 explains that during the end-Permian: (i) corals disappeared but their unskeletonized relatives, the sea anemones, did not, (ii) skeletonised dasyclad green algae disappeared, but multiple unskeletonized sister groups did not, and (iii) red algae disappeared but a 10 large number of uncalcified clades persisted.

\subsection{Important areas of refugia}

A seawater $\mathrm{pH}$ trigger for mass marine extinctions necessitates that depth-dependent variations in oceanic $\mathrm{pH}$ be evidenced by specific extinction patterns. For example, the knowledge that seawater $\mathrm{pH}$ did not exceed the critical 7.9 threshold at depths below 150-200 m during the end-Cretaceous event (Palmer et al., 1998), alludes to the preferential survival of the calcareous organisms that inhabited these deeper depths. For example: (i) more than $90 \%$ of surface (planktic) foraminifera disappeared abruptly at the boundary, whilst benthic populations remained largely unaffected (Culver, 2003); (ii) shallow water echinoderm (sea-urchins) species suffered high extinction 20 rates, whilst deep-water species were much less affected (Jeffery, 2001); (iii) the ammonites (shelled nektobenthic cephalopods) suffered complete extinction, whilst their deeper residing relative, the nautilus, escaped unaffected (Marshall and Ward, 1996).

The functioning of deep-sea locations as important areas of refugia also reconciles the recovery pattern of calcareous coralline algae following the end-Cretaceous event. In this case, it was the coralline species that were able to photosynthesize at low-light intensities and therefore had a wide (escape) depth range $(0-268 \mathrm{~m})$ that initially recolonized the shallower areas (Aguirre et al., 2007). The inference being, that the survival and re-emergence of so-called "Lazarus" taxa was reliant on the continuous

BGD

5, 2401-2423, 2008

Mass extinctions past and present

S. A. Wooldridge

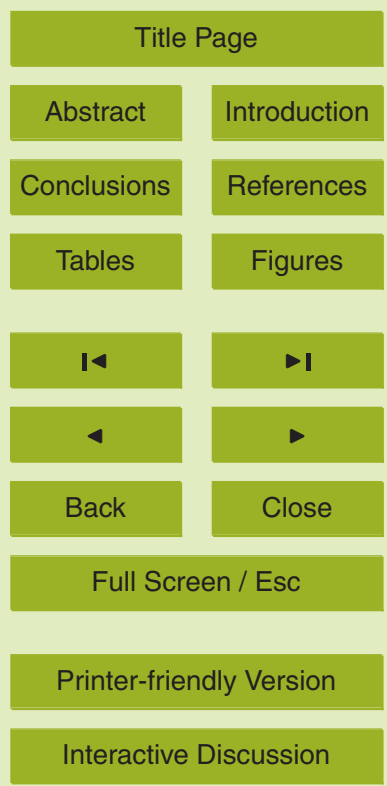


co-occurrence of the multiple physiological requirements (e.g. light, temperature etc.) of an organism within the reduced habitat "envelope" for which urease activity remained viable.

BGD

$5,2401-2423,2008$

\subsection{Patterns of recovery}

5 A seawater $\mathrm{pH}$ trigger for mass marine extinctions necessitates that the recovery ("Lazarus effect") and origination of new urease-dependent species, will be delayed until the oceanic conditions have cleared the relevant $\mathrm{pH}$ "dead zone". Several pieces of evidence suggest that this represented a multimillion year process within ocean surface waters: (i) "Reef gaps" occur after all five mass extinctions (Wood, 1999) and record intervals (>2-3 Myr) when reefs simply did not grow; (ii) "Strangelove" oceans have been identified for the end-Permian (Rampino and Caldeira, 2005), end-Triassic (Ward et al., 2001), and end-Cretaceous (D'Hondt et al., 1998), and record intervals (>2-3 Myr) when the flux of organic matter to the deep ocean was significantly diminished. Recent evidence suggests that carbonate material is required to "ballast" 15 organic material to the deep ocean (Armstrong et al., 2002). Thus, although surface ocean productivity may have recovered relatively quickly (e.g. via silica-secreting organisms) it would not have been until the return of conditions suitable for calcareous planktic species, that the deep sea "biological pump" would have restarted with full efficiency. Geochemical records from the end-Cretaceous extinction event that link the 20 recovery of planktic foraminifera with the recovery of marine carbon cycling (D'Hondt et al., 1998) appear to support this suggestion.

\section{Terrestrial paleophysiological evidence}

\subsection{Floral extinction patterns}

As already outlined, urease plays an important role in the germination and early de-

velopment of seedlings - with urease inhibition blocking seed germination (Zonia et al.
Mass extinctions past and present

S. A. Wooldridge

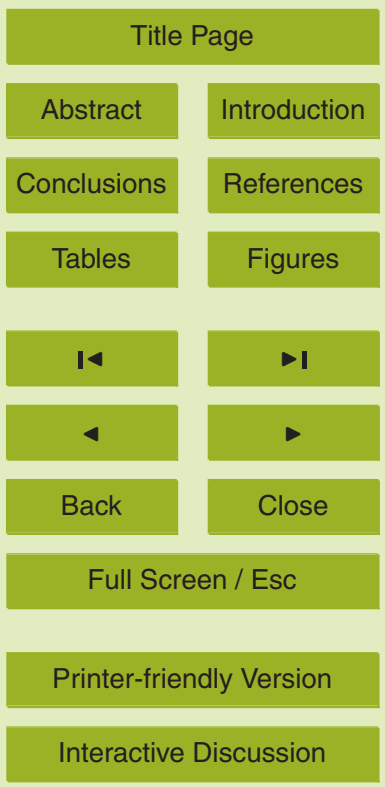

Interactive Discussion 
1995). The reproductive mode of ferns via spores (and not seeds) is thus consistent with the temporary increase in the number of ferns relative to other terrestrial plants (i.e. "fern spikes") following the extinction events at the end-Permian (Retallack, 1995), end-Triassic (Tanner et al., 2004), and end-Cretaceous (Vajda et al., 2001). Such an 5 explanation is also consistent with the preferential demise and ultimate extinction of seeding varieties of ferns, known as Pteridosperms (or "seed ferns").

\subsection{Aminota}

Amniotes include most of the land-dwelling vertebrates alive today, namely, mammals (including humans), turtles, sphenodon, lizards, snakes, crocodylians and birds. The amniotic egg is a major shared character of the Amniotes, though some components of the amniotic egg have been variously modified. For example, placental mammals have suppressed the egg shell and yolk sac, and elaborated the amniotic membranes to enable nutrients and wastes to pass directly between mother and embryo. Sometime during the evolutionary radiation of the Aminotes, the urease enzyme and other allantoin-degrading enzymes were lost (Urich, 1994) - causing purine degradation to become much less complete in comparison to the lower invertebrates. In agreement with the urease-inhibition kill mechanism, the Amniotes demonstrated preferential survival during the end-Cretaceous mass extinction (Benton and King, 1989) - the dinosaurs being a major exception.

\subsection{The Dinosaur enigma}

Indicative of their evolutionary origin, modern amniotes still retain redundant genes and transcripts for the allantoin-degrading enzymes, including urease (Vigetti et al., 2003). Is it possible that the dinosaurs preserved the function of urease until their eventual demise? One plausible place to test this suggestion is the fossilized dinosaur egg record. Evolutionary modifications to the amniote egg has culminated in the modern avian egg - whose hard $\mathrm{CaCO}_{3}$ shell is impervious to moisture loss but permits respi-
BGD

$5,2401-2423,2008$

Mass extinctions past and present

S. A. Wooldridge

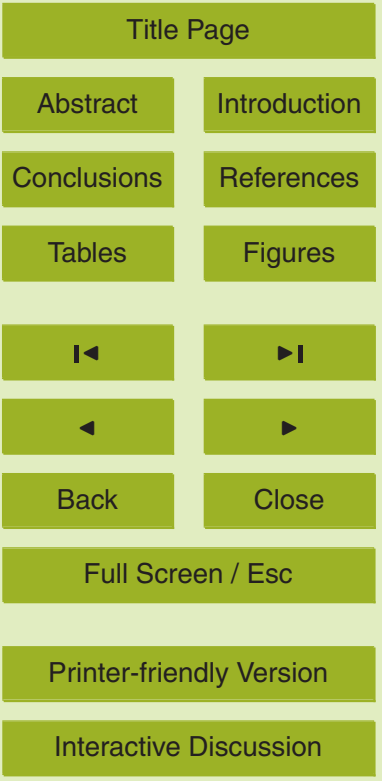

Interactive Discussion 
ratory gas exchange. Whilst urease is no longer utilised for egg development, a similar enzyme, adenosine deaminase, fulfils the ammonia-forming role in the biological deposition of $\mathrm{CaCO}_{3}$ (Campbell and Speeg, 1969). Such adaptive modification in the mode of egg development and nitrogen excretion most certainly did not involve the synthe5 sis of these new enzymatic pathways de novo. Instead, pre-existing systems must have gradually assumed the new functions. However, paleobiological considerations arising from fossilized dinosaur eggs may support the retention of the urease pathway, since the expected $\mathrm{pH}$-dependent inhibition of urease during the late-Cretaceous is evidenced by disruption to the reproductive process; both the internal biominerali10 sation process associated with egg shell production, and the posthumous process of embryo nourishment and development. For example, an increased incidence of both thin eggs shells and abnormal eggs with multiple shell layers has been reported for the latter stages of the late-Cretaceous (Erben et al., 1979; Hirsch, 1989; Zhao et al., 2002; Jackson et al., 2004). The pathological consequence of both egg types has been 15 considered (Erben et al., 1979) - with shell repetition causing suffocation of the embryo, and a reduction in shell thickness promoting shell breakage and dehydration of the embryo. Beyond the egg shell abnormalities, it is also well established that very few late-Cretaceous dinosaur eggs actually contain embryos (Carpenter et al., 1994). The frequent absence of "resportion craters" in the mammillary knobs of the egg shells indicate either a lack of fertilization of the eggs or the perishing of the embryo prior to the calcification of its skeletal bones (Erben et al., 1979). Inhibition of urease can explain such embryogenesis dysfunction, since reduced liberation of nitrogenous growth precursors from the compounds stored within the aminote yolk sac would abruptly stall embryonic development. It stands to reason, that embryonic dysfunction arising from either pathological eggshells or development failure could have triggered the mass extinction of the dinosaur - with populations simply failing to reproduce as rapidly as their members died. Such an explanation negates the need to rely exclusively on catastrophic outcomes to explain the demise of the dinosaur. Rather, it instead focuses attention on the biological impact of global cooling and declining $p \mathrm{CO}_{2}$ - though the

BGD

$5,2401-2423,2008$

Mass extinctions past and present

S. A. Wooldridge

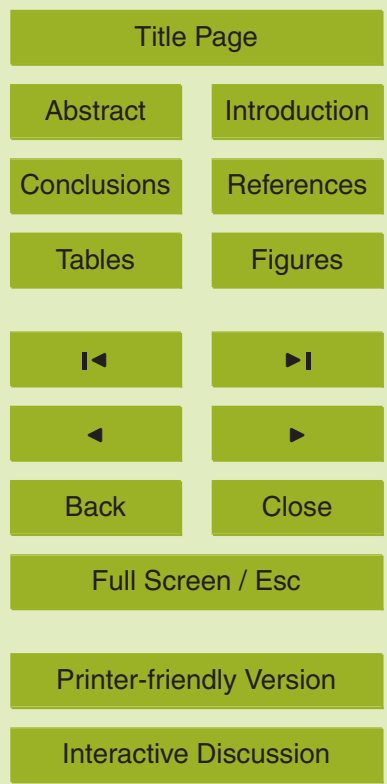

Interactive Discussion 
"impact winter" that is predicted to have accompanied the suggested bolide impact (Alverez et al., 1980) may have finalised the process. Late-Cretaceous cooling would have been particularly disadvantageous for the dinosaurs, as the thermal inertia conferred by their large body size would have conspired against them (Spotalia et al., 5 1973). Ultimately, body temperatures may have cooled sufficiently to interfere with the acid-base status of circulatory body fluids. The colder conditions and declining atmospheric $p \mathrm{CO}_{2}$ is also likely to have impacted upon the $\mathrm{pH}$ of the embryonic fluids in the externally nested eggs. Evidence showing that dinosaurs survived the longest in warm tropical locations (reviewed by Sloan et al., 1986) is consistent with these suggestions.

\section{An impending anthropocene extinction?}

Over the next century, if anthropogenic $\mathrm{CO}_{2}$ emissions proceed at the rates predicted by the IPCC scenarios (IPCC, 2001), then the identified $p \mathrm{CO}_{2}$ threshold concentration of 560 ppmv may be exceeded as early as 2050 (Fig. 3). Whilst the direct climatic impacts of this overshoot remain difficult to quantify with certainty, simple extrapolation of

15 the central tenets of the urease hypothesis suggests that there is little doubt regarding the disruption and mass mortality that it will initiate within organisms that are heavily reliant upon the urease enzyme. Previous mass extinction events appear to have guided the evolutionary process away from urease-dependence in higher vertebrate animals, but the threat remains for the lower invertebrates and plant communities. Importantly, these at-risk ecosystem elements are fundamental to: (i) the productive food chains, (ii) the essential habitat, and (iii) the stable climate cycles, upon which the higher vertebrate animals (including humans) rely for their survival. Of particular note is the potential for a collapse in ocean productivity to initiate rapid greenhouse warming (Rampino and Caldeira, 2005). In this case, the cessation of marine biological export of organic carbon from the surface would cause an increase in surface-ocean dissolved inorganic carbon, some of which would leak into the atmosphere to increase atmospheric $p \mathrm{CO}_{2}$. Modelling results suggest that a cessation of productivity today would

BGD

$5,2401-2423,2008$

Mass extinctions past and present

S. A. Wooldridge

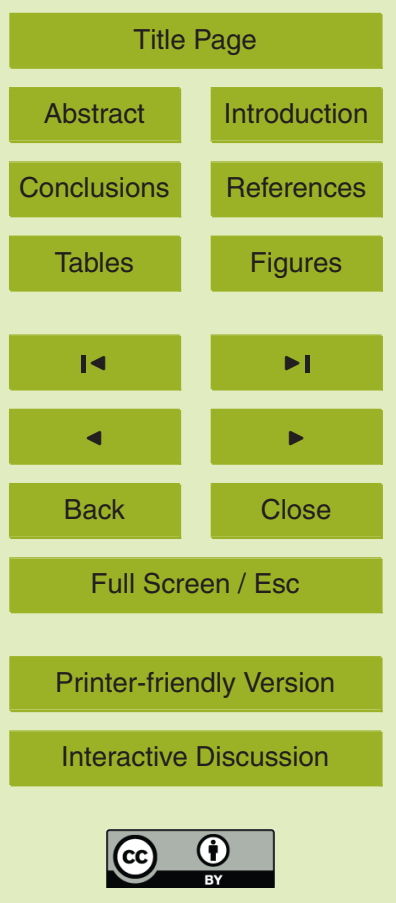


result in a rapid doubling of $p \mathrm{CO}_{2}$ (Rampino and Caldiera, 2005). It is therefore a plausible scenario that a collapse of ocean productivity occurring at $560 \mathrm{ppm}$ could trigger a rapid "post-apocalyptic" rise in $p \mathrm{CO}_{2}$ levels beyond $1000 \mathrm{ppm}$ - leading to rapid global warming of $\sim 3-6^{\circ} \mathrm{C}$. Recovery of atmospheric $p \mathrm{CO}_{2}$ from such a perturbation would 5 be governed by the time scale of equilibrium of the ocean chemistry with the carbonate system ( $c 10^{4}$ years) (Archer et al., 1997). Post-apocalyptic greenhouse spikes of similar duration have been associated with previous mass extinctions (Retallack, 2005), and may be responsible for triggering additional climate change dependent kill responses (Elewa, 2008). Clearly, the urease hypothesis forewarns of the global im-

10 perative that atmospheric $p \mathrm{CO}_{2}$ levels are stabilised well below 560 ppmv. This will require the development of technologies and solutions that are presently unavailable thus demanding our immediate attention and resources.

\section{Concluding comments}

In this paper, the $\mathrm{pH}$-dependent inactivation of a single specific enzyme, urease, has 15 been proposed as a unifying kill-mechanism for global mass extinction events. Considerable descriptive detail has been put forward to ensure that the fundamental tenets of the hypothesis are testable. For like any hypothesis, it is put forward to tested, modified and if found wanting, to be falsified and rejected (Popper, 1959). There are a number of ways this testing can be conceived. For the experimentalist, testing of the processes and sequence of events outlined in this paper provides an obvious starting point. For the theorist, the wider reaching implications of the hypothesis can be extrapolated to ensure their fidelity with the holistic earth-climate system. The immediacy with which this scientific testing must proceed however cannot be overstated, for if true, the consequences of failure or inaction in this matter are unimaginably shocking.

BGD

$5,2401-2423,2008$

Mass extinctions past and present

S. A. Wooldridge

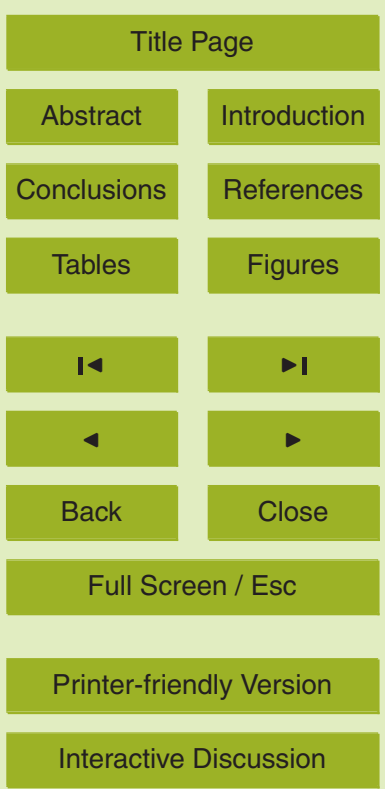




\section{References}

Abolinš-Krogis, A.: The effect of carbonic anhydrase, urea and urease on the calcium carbonate deposition in the shell-repair membrane of the snail, Helix pomatia, Cell Tissue Res., 244, 655-660, 1986.

5 Aguirre, J., Baceta, J. I., and Braga, J. C.: Recovery of marine primary producers after the Cretaceous-Tertiary mass extinction: Paleocene calcareous red algae from the Iberian Peninsula, Palaeogeogr. Palaeoclimatol. Palaeoecol., 249, 393-411, 2007.

Alvarez, L. W., Alvarez, W., Asaro, F., and Michel, H. V.: Extraterrestrial cause for the Cretaceous-Tertiary extinction - experimental results and theoretical interpretation, Science, 10 208, 1095-1108, 1980.

Archer, D., Kheshgi, H., and Maier-Reimer, E.: Multiple timescales for neutralization of fossil fuel $\mathrm{CO}_{2}$, Geophys. Res. Lett., 24, 405-408, 1997.

Armstrong, R. A., Lee, C., Hedges, J. I., Honjo, S., and Wakeham, S. G.: A new mechanistic model for organic carbon fluxes in the ocean based on the quantitative association of POC

15 with ballast materials, Deep-Sea Res., 49, 219-236, 2002.

Barnes, D. J. and Crossland, C. J.: Urease activity in the staghorn coral, Acropora acuminata, Comp. Biochem. Physiol., 55B, 371-376, 1976.

Bekheet, I. A., Kandil, K. M., and Shaban, N. Z.: Studies on urease extracted from Ulva lactuca, Hydrobiologia, 116/117, 580-583, 1984.

20 Benton, M. J. and King, P. W.: Mass extinctions among tetrapods and the quality of the fossil record (and discussion), Philos. Trans. R. Soc. London Ser. B, 325, 369-386, 1989.

Brookbank, J. W. and Whiteley, A. H.: Studies on the urease of the eggs and embryo of the sea urchin, Strongylocentrotus purpuratus, Biol. Bull., 107, 57-63, 1954.

Caldeira, K.: Phanerozoic ocean chemistry and anthropogenic ocean acidification, Goldschmidt2007, Cologne, Germany, 19-24 August 2007, A140, 2007.

Caldeira, K. and Berner, R. A.: Seawater pH and atmospheric carbon dioxide, Science, 286, $2043 a, 1999$.

Campbell, J. W. and Speeg, K. V.: Ammonia and biological deposition of calcium carbonate, Nature, 224, 725-726, 1969.

30 Cantón, F. R., Suárez, M. F., and Cánovas, F. M.: Molecular aspects of nitrogen mobilisation and recycling in trees, Photosynthesis Res., 83, 265-278, 2005.

Carpenter, K., Hirsch, K. F., and Horner, J. R. (Eds.): Dinosaur Eggs and Babies, Cambridge
BGD

5, 2401-2423, 2008

Mass extinctions past and present

S. A. Wooldridge

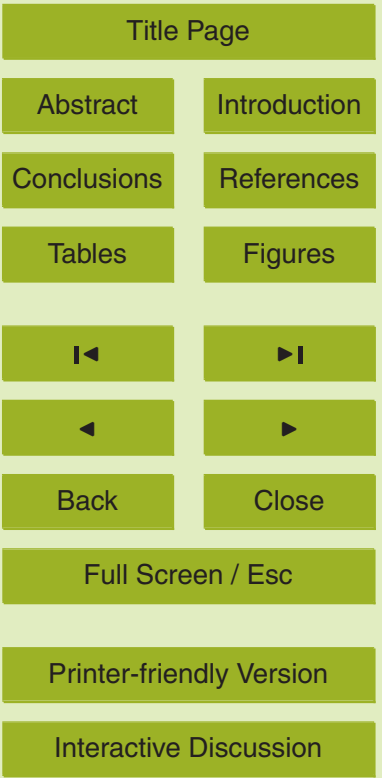


Univ. Press, Cambridge, 1994.

Crossland, C. J. and Barnes, D. J.: The role of metabolic nitrogen in coral calcification, Mar. Biol., 28, 325-332, 1974.

Culver, S. J.: Benthic foraminifera across the Cretaceous-Tertiary (KT) boundary: a review, Mar. Micropaleontol., 47, 177-226, 2003.

D'Hondt, S., Donaghay, P., Zachos, J. C., Luttenberg, D., and Lindinger, M.: Organic carbon fluxes and the ecological recovery from the Cretaceous-Tertiary mass extinction, Science, 282, 276-279, 1998.

Dauphin, Y., Cusack, M., and Ortlieb.: Nanogranules in carbonate skeletons: a universal scheme? Geophys. Res. Abst., 9, 02261, 2007.

Elewa, A. M. T. (Ed): Mass extinction, Springer-Verlag, Berlin, 2008.

Erben, H., Hoefs, J., and Wedephl, K.: Paleobiological and isotopic studies of egg shells from a declining dinosaur species, Paleobiol., 5, 380-414, 1979.

Estiu, G. and Merz, K. M.: The hydrolysis of urea and the proficiency of urease, J. Am. Chem. 15 Soc., 126, 6932-6944, 2004.

Finzi, A. C., Moore, D. J. P., DeLucia, E. H., and Lichter, J.: Progressive nitrogen limitation of ecosystem processes under elevated $\mathrm{CO}_{2}$ in a warm-temperate forest, Ecology 87, 15-25, 2006.

François, L., Grard, A., and Goddéris, Y.: Modelling atmospheric $\mathrm{CO}_{2}$ changes at geological time scales, In: Pre-Cambium to Palaeozoic palaeopalynology and paleobotany, Edited by: Steemans, P. and Jabvaux, E., Carnets de Géologie / Notebooks on Geology, Brest, Memoir 2005/02, Abstract 02 (CG2005_M02/02), 2005.

Gazeau, F., Quiblier, C., Jansen, J. M., Gattuso, J. P., Middelburg, J. J., and Heip, C. H. R.: Impact of elevated $\mathrm{CO}_{2}$ on shellfish calcification, Geophys. Res. Lett., 34, L07603, doi:10.1029/2006GL028554, 2007.

Ha, N. C., Oh, J. Y., Sung, K. A., Cha, K. A., Lee, M. H., and Oh, B. H.: Supramolecular assembly and acid resistance of Helicobacter pylori urease, Nature Struct. Biol., 8, 867-879, 2001.

Hirsch, K. F.: Interpretations of Cretaceous and pre-Cretaceous eggs and shell fragments, In: Dinosaur Tracks and Traces, Edited by: Gillette, D.D. and Lockley, M.G., Cambridge University Press, New York, 89-97, 1989.

IPCC 2001, In: Climate Change 2001. The Scientific Basis. The Contribution of Working Group 1 to the Third Assessment Report of the Intergovernmental Panel on Climate Change, Edited
BGD

$5,2401-2423,2008$

Mass extinctions past and present

S. A. Wooldridge

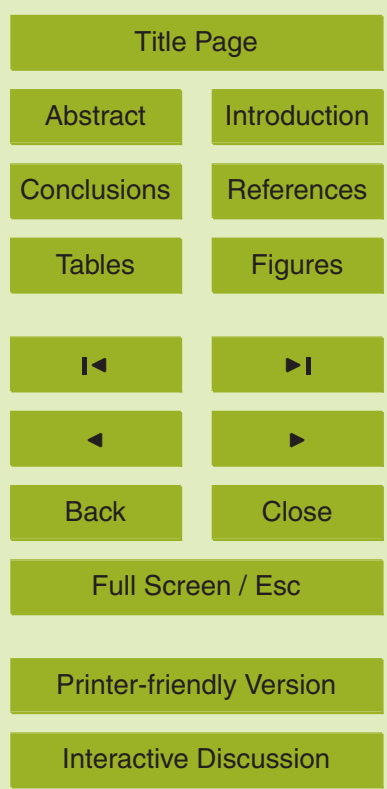


by: Houghton, J. T. et al., Cambridge Univ. Press, New York, 2001.

Jackson, F. D., Garrido, A., Schmitt, J. G., Chiappe, L. M., Dingus, L., and Loope, D. B.: Abnormal, multilayer titanosaur (Dinosauria: Sauropoda) eggs from in situ clutches at the Auca Mahuevo locality, Neuquén Province, Argentina, J. Vertebr. Paleontol., 24, 913-922, 2004.

5 Jeffery, C. H.: Heart urchins at the Cretaceous-Tertiary boundary: a tale of two clades, Paleobiol., 27, 140-158, 2001.

Johnston, A. M.: The effect of environmental variables on ${ }^{13} \mathrm{C}$ discrimination by two marine phytoplankton, Mar. Ecol. Progr. Ser., 132, 257-263, 1996.

Jones, V. M. and Boulter, D.: Arginine metabolism in germinating seeds of some members of the leguminosae, New Phytol., 67, 925-934, 1968.

Keller, G.: The end-cretaceous mass extinction in the marine realm: year 2000 assessment, Planet. Space Sci., 49, 817-830, 2001.

Kiessling, W., Aberhan, M., Brenneis, B., and Wagner, P. J.: Extinction trajectories of benthic organisms across the Triassic-Jurassic boundary, Palaeogeogr. Palaeoclimatol. Palaeoecol., 244, 201-222, 2007.

Knoll, A. H., Bambach, R. K., Payne, J. L., Priss, S., and Fischer, W. W.: Paleophysiology and end-Permian mass extinction, Earth Planet. Sci. Lett., 256, 295-313, 2007.

Krajewska, B. and Ciurli, S.: Jack bean (Canavalia ensiformis) urease. Probing acid-base groups of the active site by pH variation, Plant Physiol. and Biochem., 43, 651-658, 2005.

Makino, A. and Mae, T.: Photosynthesis and plant growth at elevated levels of $\mathrm{CO}_{2}$, Plant Cell Physiol., 40, 999-1006, 1999.

Marshall, C. R. and Ward, P. D.: Sudden and gradual molluscan extinctions in the latest Cretaceous of the western European Tethys, Science, 274, 1360-1363, 1996.

McGhee, G. R., Sheehan, P. M., Bottjer, D. J., and Droser, M. L.: Ecological ranking of Phanerozoic biodiversity crises: ecological and taxonomic severities are decoupled, Palaeogeogr. Palaeoclimatol. Palaeoecol., 211, 289-297, 2004.

Palmer, M. R., Pearson, P. N., and Cobb, S. J.: Reconstructing past ocean pH-depth profiles, Science, 282, 1468-1471, 1998.

Pedrozo, H. A., Schwart, Z., Dean, D. D., Harrison, J. L., and Campbell, J. W.: Evidence for the involvement of carbonic anhydrase and urease in calcium carbonate formation in the gravity-sensing organ of Aplysia californica, Calcif. Tissue Int., 61, 247-255, 1997.

Popper, K. R. (Ed.): The logic of scientific discovery, Routledge, London, 1959.

Racki, G.: Silica-secreting biota and mass extinctions: survival, patterns and processes,
BGD

$5,2401-2423,2008$

Mass extinctions past and present

S. A. Wooldridge

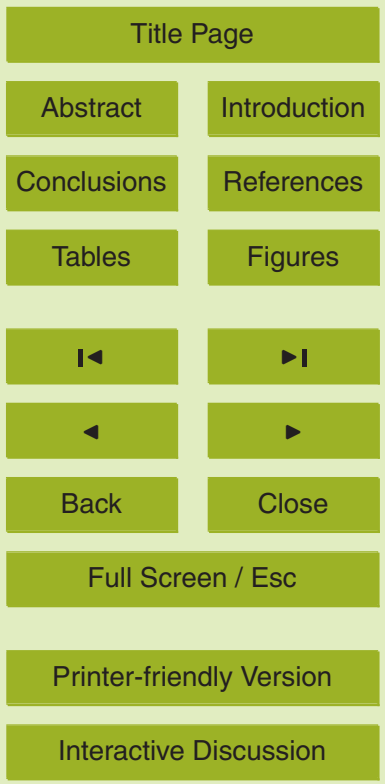


Palaeogeogr. Palaeoclimatol. Palaeoecol., 154, 107-132, 1999.

Rampino, M. R. and Caldeira, K.: Major perturbation of ocean chemistry and a "Stangelove Ocean" after the end-Permian mass extinction, Terra Nova, 17, 554-559, 2005.

Raup, D. M. and Sepkoski, J. J.: Mass extinctions in the marine fossil record, Science, 215, 1501-1503, 1982.

Reeves, R. B.: The interaction of body temperature and acid-base balance in ectothermic vertebrates, Annu. Rev. Physiol., 39, 559-586, 1977.

Reich, P. B., Hobbie, S. E., Lee, T., Ellsworth, D. S., West, J. B., Tilman, D., Knops, J. M. H., Naeem, S., and Trost, J.: Nitrogen limitation constrains sustainability of ecosystem response 10 to $\mathrm{CO}_{2}$, Nature, 440, 922-925, 2006.

Retallack, G. J.: Permian -Triassic life crises on land, Science, 267, 77-79, 1995.

Retallack, G. J.: An unfortunate series of global atmospheric greenhouse spikes, Geological Society of America Abstracts with Programs, 37, 86, 2005.

Rohde, R. A. and Muller, R. A.: Cycles in fossil diversity, Nature, 434, 208-210, 2005.

15 Shirayama, Y. and Thorton, $\mathrm{H}$.: Effect of increased atmospheric $\mathrm{CO}_{2}$ on shallow water marine benthos, J. Geophys. Res., 110, C09S08, doi:10.1029/2004JC002618, 2005.

Sirko, A. and Brodzik, R.: Plant ureases: roles and regulation, Acta Biochim. Polon., 47, 11891195, 2000.

Sloan, R. E., Rigby, J. K., Van Vallen, L. M., and Gabriel, D.: Gradual dinosaur extinction and simultaneous ungulate radiation in the Hell Creek formation, Science, 232, 629-633, 1986.

Spotila, J. R., Lommen, P. W., Bakken, G. S., and Gates, D. M.: A mathematical model for body temperature of large reptiles: implications for dinosaur ecology, Am. Nat., 107, 391-404, 1973.

Tanner, L. H., Lucas, S. G., and Chapman, M. G.: Assessing the record and causes of Late 25

Triassic extinctions, Earth Sci. Rev., 65, 103-139, 2004.

Tentori, E. and Allemand, D.: Light-enhanced calcification and dark decalcification in isolates of the soft coral Cladiella sp. during tissue recovery, Biol. Bull., 211, 193-202, 2006.

Todd, C. D., Cooke, J. E. K., Mullen, R. T., and Gifford, D. J.: Regulation of loblolly pine (Pinus taeda L.) arginase in developing seedling tissue during germination and post-germative 30 growth, Plant Mol. Biol., 45, 555-565, 2001.

Urich, K. (Ed.): Comparative animal biochemistry, Springer-Verlag, Heidelberg, 1994.

Vajda, V., Taine, I. J., and Hollis, C. J.: Indication of global deforestation at the CretaceousTertiary boundary by New Zealand fern spike, Science, 294, 1700-1702, 2001.
BGD

$5,2401-2423,2008$

Mass extinctions past and present

S. A. Wooldridge

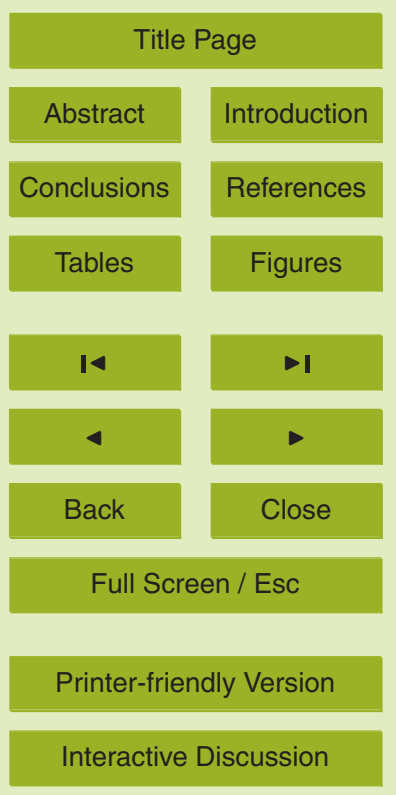


van de Schootbrugge, B., Tremolada, F., Rosenthal, Y., Bailey, T. R., Feist-Burkhardt, S., Brinkhuis, H. Pross, J., Kent, D. V., and Falkowski, P. G.: End-triassic calcification crisis and blooms of organic-walled "disaster species", Palaeogeogr. Palaeoclimatol. Palaeoecol., 244 126-141, 2007.

5 Vigetti, D., Binelli, G., Monetti, C., Prati, M., Bernardini, G., and Gornati, R.: Selective pressure on the Allantoicase gene during vertebrate evolution, J. Mol. Evol., 57, 650-658, 2003.

Ward, P. D., Haggart, J. W., Carter, E. S., Wilbur, D., Tipper, H. W., and Evans, T.: Sudden productivity collapse associated with the Triassic-Jurassic boundary mass extinction, Science, 292, 1148-1151, 2001.

10 Ward, P. D., Garrison, G. H., Haggart, J. W., Kring, D. A., and Beattie, M. J.: Isotopic evidence bearing on Late Triassic extinction events, Queen Charlotte Islands, British Columbia, and implications for the duration and cause of the Triassic/Jurassic mass extinction, Earth Planet. Sci. Lett., 224, 589-600, 2004.

Witte, C. P., Tiller, S., Isidore, E., Davies, H. V., and Taylor, M. A.: Analysis of two alleles of the urease gene from potato: polymorphisms, expression, and extensive alternative splicing of the corresponding mRNA, J. Exp. Bot., 56, 91-99, 2005.

Wood, R. (Ed.): Reef Evolution, Oxford University Press, Oxford, 1999.

Yates, K. K., Halley, R. B.: $\mathrm{CO}_{3}^{2-}$ concentration and $p \mathrm{CO}_{2}$ thresholds for calcification and dissolution on the Molokai reef flat, Hawaii, Biogeosciences, 3, 357-369, 2006,

20 http://www.biogeosciences.net/3/357/2006/.

Zhao, Z. K., Mao, X. Y., Chai, Z. F., Yang, G. C., Kong, P., Ebihara, M., and Zhao, Z. H.: A possible causal relationship between extinction of dinosaurs and the $K / T$ iridium enrichment in the Nanxiong Basin, South China: evidence from dinosaur eggshells, Palaeogeogr. Palaeoclimatol. Palaeoecol., 178, 1-17, 2002.

Zonia, L. E., Stebbins, N. E., and Polacco, J. C.: Essential role of urease in germination of nitrogen-limited Arabidopsis thaliana seeds, Plant Physiol., 107, 1097-1103, 1995.

BGD

$5,2401-2423,2008$

Mass extinctions past and present

S. A. Wooldridge

Title Page

Abstract

Introduction

Conclusions

References

Tables

Figures

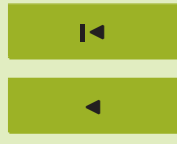

$\rightarrow$

Back

Close

Full Screen / Esc

Printer-friendly Version

Interactive Discussion 


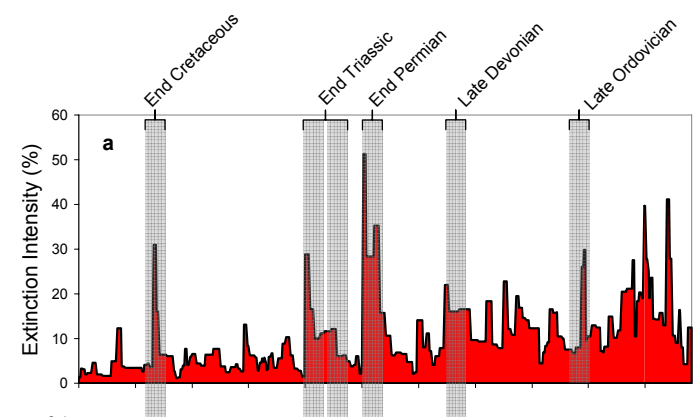

BGD

5, 2401-2423, 2008

Mass extinctions past and present

S. A. Wooldridge

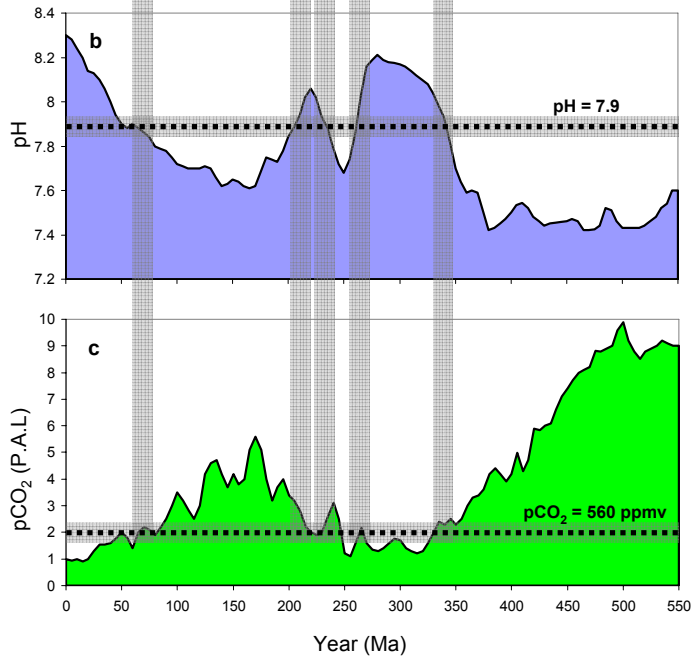

Title Page

Abstract

Introduction

Conclusions

References

Tables

Figures

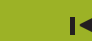

4

\section{$>$ I}

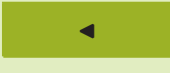

$>$

Back

Close

Full Screen / Esc

Fig. 1. The "big five" mass extinction events of the Phanerozoic. (a) Marine extinction intensity (\%), displayed as the fraction of marine genera that are present in each interval of time but do not exist in the following interval (adapted from Rohde and Muller, 2005). (b) Simulated evolution of surface ocean $\mathrm{pH}$ assuming constant surface-ocean carbonate mineral saturation (Caldeira, 2007). (c) Simulated evolution of atmospheric $\mathrm{CO}_{2}$ (François et al., 2005), with $\mathrm{CO}_{2}$ levels expressed as multiples of the Pre-industrial Level (P.A.L=280 ppmv). 
BGD

$5,2401-2423,2008$

'dead zone'

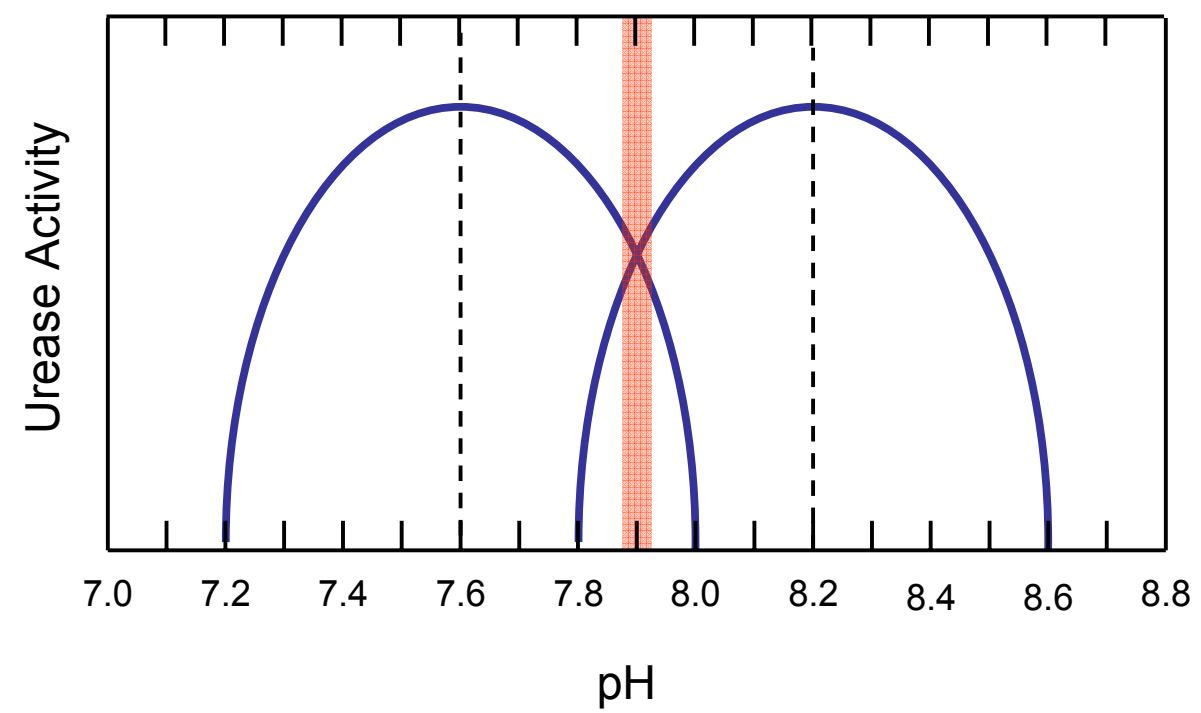

Fig. 2. $\mathrm{pH}$-activity profile of the urease enzyme extracted from the scleractinian coral Acropora acuminata (adapted from Barnes and Crossland, 1976). An enzymatic "dead zone" is indicated at $\mathrm{pH}=7.9$.

\section{Mass extinctions past and present}

S. A. Wooldridge

Title Page

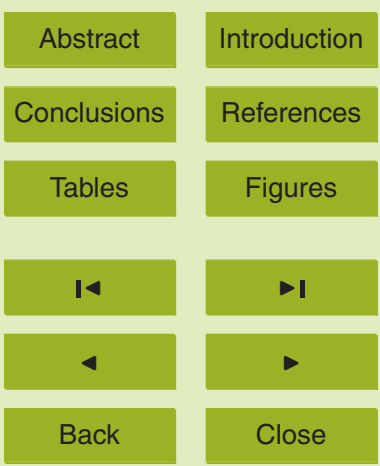

Full Screen / Esc

Printer-friendly Version

Interactive Discussion 
BGD

$5,2401-2423,2008$

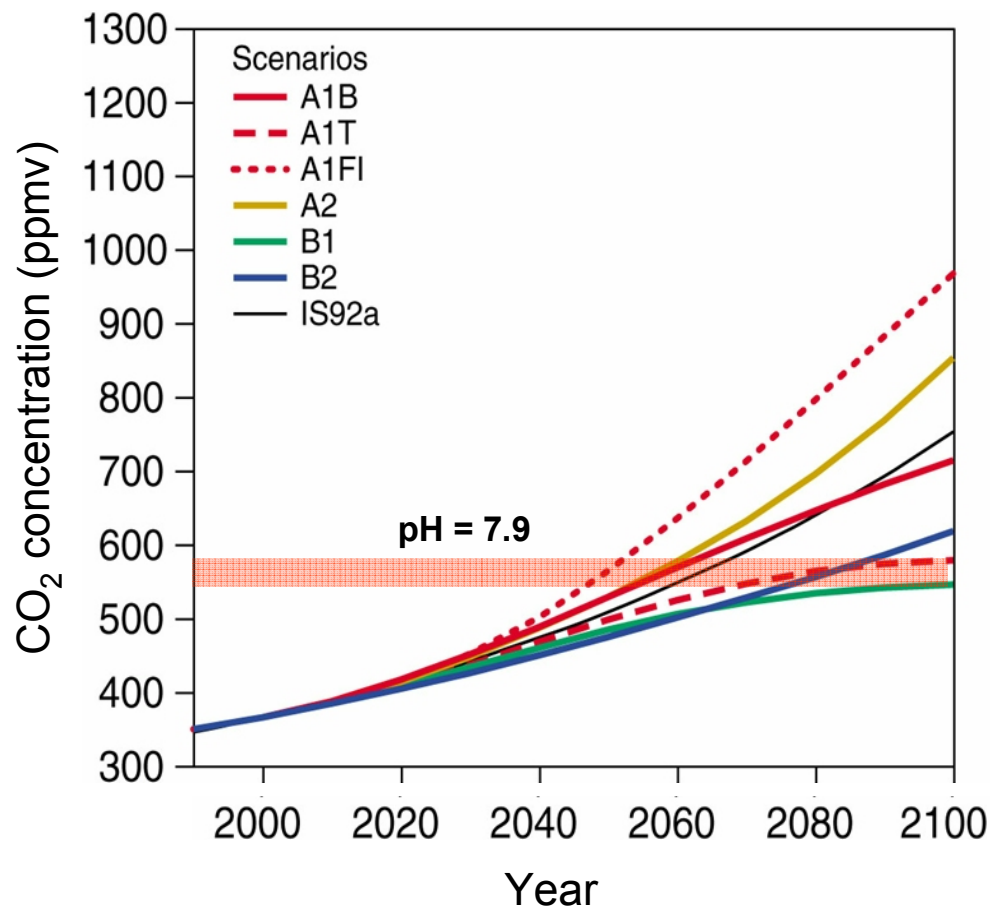

\section{Mass extinctions} past and present

S. A. Wooldridge

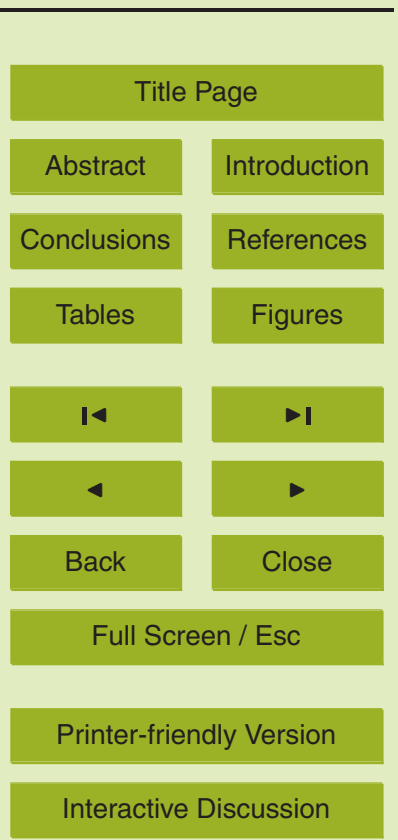

Fig. 3. Projected rates of change in atmospheric $\mathrm{CO}_{2}$ concentration for a range of SRES scenarios (IPCC, 2001). The projections highlight that the inhibition of urease (surface ocean $\mathrm{pH}=7.9$ ) could be triggered as early as 2050 .
Interactive Discussion 